\title{
PENYUSUNAN PERANGKAT PEMBELAJARAN PADA MATERI RUANG LINGKUP BIOLOGI KELAS X SMA
}

\author{
Titin, Ella Nartia Dara \\ Program Studi Pendidikan Biologi FKIP Untan \\ Email:titinbasuki@rocketmail.com
}

\begin{abstract}
This research aimed to produce a feasible learning set used on scope biology material in $X^{\text {th }}$ Grade of SMA. The learning set extended over documentary film medium, lesson plan, student worksheet, and evaluation test on scope biology material in $X^{\text {th }}$ Grade of SMA Negeri 1 Sengah Temila. Research menthod was performed with descriptive analysis in the form of validity and learning set effectivity. From the result of the research yielded: learning set in the form of documentary film medium, lesson plan, student worksheet, evaluation test, were feasible to use as leraning set on scope biology material in $X^{\text {th }}$ Grade of SMA Negeri 1 Sengah Temila. The set effectiveness, resulted an average score of study archievement by the amount of 75,78 and as much as 83,37\% of students who have been attained their KKM.

Keywords: feasible learning, scope of biology, validity, effectivity.
\end{abstract}

\begin{abstract}
Menurut Undang-Undang
Sistem Pendidikan No. 20 Tahun

2003 pembelajaran adalah proses interaksi peserta didik dengan pendidik dan sumber belajar pada suatu lingkungan belajar (Majid, 2013). Sedangkan menurut Suherman (dalam Jihad dan Haris, 2012) menyatakan pembelajaran pada hakikatnya merupakan proses komunikasi antara peserta didik dengan pendidik serta antar peserta didik dalam rangka perubahan sikap. Hal tersebut menunjukan bahwa pada proses pembelajaran perlu adanya komunikasi dan interaksi, yaitu penyampaian materi dari guru kepada siswa. Penyampaian materi tersebut disampaikan guru biasanya dibantu dengan menggunakan media pembelajaran. Media pembelajaran berfungsi untuk memperjelas penyajian pesan dan informasi sehingga dapat memperlancar dan
\end{abstract}

meningkatkan proses dan hasil belajar (Arsyad, 2011).

Pembelajaran pada hakikatnya merupakan proses komunikasi antara siswa dengan pendidik serta antara siswa dalam rangka perubahan sikap. Hal tersebut menunjukkan bahwa pada proses pembelajaran perlu adanya komunikasi dan interaksi, yaitu penyampaian materi dari guru kepada siswa. Kurikulum yang berlaku sekarang mengarahkan siswa untuk banyak beraktivitas (fisik dan mental) dalam belajar. Berdasarkan bahan pengembangan kurikulum yang diterbitkan oleh Kemendikbud disebutkan bahwa strategi peningkatan efektivitas pembelajaran dalam segi pemahaman adalah pembelajaran yang mengedepankan pengalaman personal melalui observasi (menyimak, melihat, membaca dan mendengar), asosiasi, bertanya, menyimpulkan dan 
mengkomunikasikan (Ma'rifah dan Suryadarma, 2015).

Belajar biologi akan lebih mudah dan jelas jika objek yang sedang dipelajari dapat diamati secara langsung. Namun tidak semua objek pembelajaran biologi dapat diamati secara langsung, diperlukan perangkat pembelajaran untuk membantu memperjelas pesan pembelajaran sehingga persepsi siswa dengan objek yang sebenarnya menjadi sama. Perangkat pembelajaran adalah sejumlah bahan, alat, media, petunjuk dan pedoman yang akan digunakan dalam proses pembelajaran (Aziz, 2013). Perangkat pembelajaran tersebut digunakan guru sebagai sarana pada proses pembelajaran di kelas. Tujuan adanya perangkat pembelajaran yaitu sebagai pendukung agar guru berhasil dalam proses pembelajaran.

Berdasarkan hasil wawancara dengan guru biologi kelas X SMA Negeri 1 Sengah Temila diperoleh informasi bahwa materi ruang lingkup biologi hasil belajar siswa masih rendah. Selain dilakukan wawancara dengan guru, dilakukan juga wawancara dengan tiga orang siswa yang telah mempelajari materi ruang lingkup biologi. Berdasarkan hasil wawancara, pada saat kegiatan pembelajaran peran siswa hanya mencatat dan mendengarkan materi yang telah disampaikan guru dengan menggunakan media power point, sehingga siswa menjadi kurang bersemangat saat mengikuti pembelajaran di kelas dan kurang memperhatikan saat guru sedang menjelaskan materi pelajaran. Selain itu siswa juga lebih banyak menghapal dalam memahami materi ruang lingkup biologi, sehingga menyebabkan siswa menjadi cepat lupa dalam mengingat materi pelajaran yang sudah disampaikan oleh guru. Hal tersebut menunjukkan bahwa pada proses pembelajaran biologi dengan media power point yang digunakan guru kurang menarik perhatian siswa untuk belajar sehingga berpengaruh terhadap hasil belajar siswa.

Materi ruang lingkup biologi materi yang isinya mencakup segala hal yang berhubungan dengan biologi. Pada Kurikulum Tingkat Satuan Pendidikan (KTSP) materi ruang lingkup biologi mempelajari tentang pengertian biologi, cabangcabang ilmu biologi, manfaat biologi bagi kehidupan, tingkat organisasi kehidupan, dan permasalahan biologi pada tingkat organisasi kehidupan. Menurut Arsyad (2011), pada proses belajar mengajar, banyak sekali pilihan media yang dapat digunakan oleh guru dalam menyampaikan materi kepada siswa diantaranya media cetak, audio, dan audio visual. Masing-masing jenis media tersebut memiliki kemampuan tersendiri dalam menjelaskan materi yang ingin disampaikan. Kerucut pengalaman belajar Edgar Dale menunjukkan bahwa belajar dengan melihat dan mendengar akan lebih baik dibandingkan hanya melihat ataupun mendengar saja dikarenakan melibatkan dua panca indera sehingga informasi akan lebih mudah diserap dan memperkuat daya ingat (Arsyad, 2011).

Menurut Sudjana dan Rivai (2010) media pembelajaran dapat memperjelas penyampaian materi pembelajaran yang disampaikan oleh guru sehingga dapat meningkatkan pemahaman siswa. Media menarik 
perhatian siswa untuk belajar karena siswa akan lebih banyak melakukan kegiatan belajar tidak hanya mendengarkan uraian dari guru. Dengan demikian media merupakan salah satu unsur penting dalam menentukan keberhasilan kegiatan pembelajaran. Pemilihan media yang tepat harus sesuai dengan tujuan pembelajaran yang ingin dicapai, sehingga fungsi utama media sebagai alat bantu pembelajaran dapat dimanfaatkan secara maksimal.

Salah satu jenis media pembelajaran yang sesuai dengan kerucut pengalaman belajar tersebut adalah media pembelajaran audio visual. Media pembelajaran audio visual yaitu media yang melibatkan indera pendengaran dan penglihatan sekaligus dalam satu proses (Munadi, 2013). Dengan menggunakan media audio visual dapat sangat membantu pada proses belajar mengajar, karena dengan media tersebut siswa dapat melakukan pengamatan, sehingga akan lebih mudah mengingat kembali. Demikian pula pengalaman yang didapat melalui pengamatan sangat membantu memperoleh pengetahuan yang lebih luas, yang akhirnya siswa akan berkembang cara berfikirnya (Darwanto, 2007). Salah satu media audio visual adalah film dokumenter. Menurut Pratista (2008) film dokumenter adalah film yang merekam kejadian sebenarnya.

Melihat permasalahan pembelajaran di kelas X SMA Negeri 1 Sengah Temila maka perlu disusun perangkat pembelajaran dengan menggunakan media film dokumenter. Jenis perangkat pembelajaran yang disusun meliputi media film dokumenter, Rencana Pelaksanaan Pembelajaran (RPP),
Lembar Kerja Siswa (LKS) dan soal evaluasi pada materi ruang lingkup biologi kelas X SMA Temila. Film dokumenter yang dibuat berupa rekaman kejadian yang dekat dengan siswa dan mengaitkannya dengan materi ruang lingkup biologi yang dipelajari sehingga diharapkan akan menjadi lebih kontekstual. Siswa dapat mengamati dan mendengar secara langsung objek apa saja yang dipelajari pada cabang-cabang biologi, manfaat biologi bagi kehidupan, berbagai tingkat organisasi kehidupan, dan permasalahan biologi pada tingkat organisasi kehidupan.

Menurut Munadi (2013) dengan menggunakan film siswa dapat melihat dan mendengar secara bersamaan dan mengakibatkan siswa lebih mudah mengingat daripada apa yang hanya dilihat atau didengar saja. Film dokumenter adalah film yang merekam kejadian sebenarnya. Film dokumenter biasanya direkam di sebuah lokasi nyata dan temanya terfokus pada subyek-subyek seperti sejarah, ilmu pengetahuan, sosial atau lingkungan. Tujuan dasarnya adalah untuk memberi pencerahan, memberi informasi, pendidikan, melakukan persuasi dan memberikan wawasan tentang dunia yang kita tinggali.

Film merupakan media yang sangat besar kemampuannya dalam membantu proses belajar mengajar. Menurut Sadiman, dkk (2011) keunggulan film dibandingkan dengan media lain yaitu sebagai berikut: a. film merupakan suatu denominator belajar yang umum, b. Film sangat baik untuk menerangkan suatu proses, c. Film dapat menampilkan kembali masa lalu dan menyajikan kembali kejadian- 
kejadian sejarah masa lalu, d. Film dapat menyajikan teori maupun praktik dari yang bersifat umum ke khusus atau sebaliknya, e. Film dapat menggunakan teknik-teknik terutama warna, gerak lambat, animasi, dan sebagainya untuk menampilkan butirbutir tertentu, f. Film dapat mendatangkan seorang ahli dan memperdengarkan suara di kelas, dan g. Film dapat memikat perhatian siswa.

Penggunaan media yang dapat terlihat oleh mata dan terdengar oleh telinga lebih mudah diingat dibandingkan dengan apa yang hanya dilihat atau didengar saja (Munadi, 2013). Menurut Munadi (2013) karakteristik media film dalam proses pembelajaran sehingga dapat meningkatkan efektifitas dan efisiensi pembelajaran, diantaranya adalah: a, Mengatasi keterbatasan jarak dan waktu, b. Mampu menggambarkan peristiwa-peristiwa masa lalu secara realistis dalam waktu yang singkat, $\mathrm{c}$. Film dapat membawa anak dari negara satu ke negara yang lain dan dari masa satu ke masa yang lain, d. Film dapat diulangi untuk menambah kejelasan, e. Pesan yang disampaikan cepat dan mudah diterima, $f$. Mengembangkan pikiran dan pendapat para siswa, g. Mengembangkan imajinasi peserta didik, h. Memperjelas hal-hal yang abstrak dan memberikan gambaran yang lebih realistis, i. Menumbuhkan minat dan motivasi.

Film dokumenter pada penelitian ini merupakan film yang merekam kejadian sebenarnya, disertai efek khusus seperti musik, teks, dan suara. Pembuatan film tersebut yaitu dengan menggabungkan video yang direkam di lingkungan sekitar, video yang direkam di laboratorium biologi, video yang diperoleh dari youtube, dan gambar yang diperoleh dari berbagai referensi yaitu internet dan buku. Isi film dokumenter tersebut memuat tentang pengertian biologi, cabang-cabang ilmu biologi, manfaat biologi bagi kehidupan, tingkat organisasi kehidupan, dan permasalahan biologi pada tingkat organisasi kehidupan. Film dokumenter tersebut berdurasi 37 menit 11 detik dan ditayangkan untuk dua kali pertemuan. Pertemuan pertama durasi film yang ditayangkan yaitu 19 menit dan pertemuan kedua durasi film ditayangkan yaitu 18 menit 11 detik.

Menurut Mulyasa (2011) Rencana Pelaksanaan Pembelajaran (RPP) adalah rencana yang menggambarkan prosedur dan manajemen pembelajaran untuk mencapai satu atau lebih kompetensi dasar yang ditetapkan dalam Standar Isi dan dijabarkan dalam silabus. Rencana Pelaksanaan Pembelajaran (RPP) merupakan rencana guru mengajar mata pelajaran tertentu, pada jenjang dan kelas tertentu, untuk topik tertentu, dan untuk satu pertemuan atau lebih. Sejalan dengan pendapat Majid (2013) ada beberapa manfaat perencanaan pembelajaran dalam proses belajar mengajar, yaitu: sebagai petunjuk arah kegiatan dalam mencapai tujuan, sebagai pola dasar dalam mengatur tugas dan wewenang bagi setiap unsur yang terlibat dalam kegiatan, sebagai pedoman kerja bagi setiap unsur, baik unsur guru maupun unsur murid, sebagai alat ukur efektif tidaknya suatu pekerjaan, sehingga setiap saat diketahui ketepatan dan kelambatan kerja, untuk bahan 
penyusunan data agar terjadi keseimbangan kerja dan untuk menghemat waktu, tenaga, alat-alat dan biaya.

Perangkat pembelajaran yang dibuat seperti Rencana Pelaksanaan Pembelajaran (RPP), Lembar Kerja Siswa (LKS), dan soal evaluasi kualitasnya juga harus diperhatikan untuk mendukung keberhasilan dalam proses pembelajaran. Jika dalam perencanaan guru kurang dalam mempersiapkan perangkat pembelajaran maka tujuan pembelajaran tidak akan tercapai. Perangkat pembelajaran yang telah disusun dapat diukur kualitasnya melalui penilaian oleh mereka yang dianggap berkompeten (expert). Perangkat pembelajaran yang telah disusun perlu diukur kualitasnya agar dapat dipertanggungjawabkan hasilnya. Untuk menyusun perangkat pembelajaran yang baik perlu penilaian serta masukan/ saran/ pertimbangan dari mereka yang dianggap berkompeten (ahlinya).

Peneliti memilih SMA Negeri 1

Sengah Temila sebagai objek penelitian karena sudah terakreditasi dan memiliki akreditasi B. Meskipun demikian ternyata masih banyak siswa yang belum mencapai nilai Kriteria Ketuntasan Minimal (KKM). Berdasarkan uraian pada latar belakang tersebut perlu dilakukan persiapan dan pelaksanaan perangkat pembelajaran yang telah disusun untuk mengetahui kelayakan perangkat pembelajaran dan kefektifannya pada materi ruang lingkup biologi. Kelas X SMA. Penelitian ini bertujuan menghasilkan perangkat pembelajaran yang layak digunakan pada materi ruang lingkup biologi kelas X SMA.

\begin{abstract}
METODE
Jenis penelitian ini adalah metode deskriptif. Tahapan yang dilakukan dalam penelitian yaitu: 1). penetapan materi pembelajaran yakni ruang lingkup biologi dan standar kompetensi yang akan dicapai siswa disesuaikan dengan silabus, 2) analisis kebutuhan yakni menjadikan materi pembelajaran menjadi lebih kontekstul, 3) penyusunan perangkat pembelajaran meliputi media film dokumenter, Rencana Pelaksanaan pembelajaran (RPP), Lembar Kerja Siswa (LKS), dan soal evaluasi beserta kisi-kisinya, dan 4) Melakukan validasi uji coba perangkat pembelajaran untuk mengetahui efektivitasnya.
\end{abstract}

Tempat yang dipilih dalam penelitian ini adalah SMA Negeri 1 Sengah Temila. Penelitian dilakukan mulai dari minggu kedua bulan september hingga minggu pertama bulan oktober 2015. Subjek penelitian adalah ahli (pakar), guru, dan siswa. Ahli (pakar) berperan untuk memperoleh data mengenai validitas perangkat pembelajaran yang terdiri dari ahli isi dari kalangan dosen dan guru biologi kelas X SMA. Siswa dan guru berperan dalam memperoleh data tentang efektivitas perangkat pembelajaran. Siswa yang dimaksud adalah siswa kelas X SMA Negeri 1 Sengah Temila.

Validasi dilakukan terhadap
perangkat pembelajaran (film dokumenter, Rencana Pelaksanaan pembelajaran (RPP), Lembar Kerja Siswa (LKS), dan soal evaluasi oleh dua orang dosen Pendidikan Biologi FKIP Universitas Tanjungpura dan satu orang guru biologi SMA Negeri 1 Sengah Temila. Validasi film dokumenter mecakup beberapa enam 
aspek antara lain: organisasi, durasi, kemanfaatan, keefektifan desain tampilan, konsistensi, dan kemudahan pengoperasian media. Validasi RPP terdiri atas empat aspek yaitu: standar kompetensi dan kompetensi dasar serta indikator telah sesuai dengan silabus, tujuan pembelajaran telah sesuai dengan indikator yang telah ditentukan pada silabus, menentukan langkah-langkah pembelajaran dan menyiapkan instrumen hasil belajar. Validasi LKS terdiri atas enam aspek yaitu: petunjuk penggunaan LKS tercantum jelas, tujuan pembelajaran sesuai indikator dalam silabus, pertanyaan yang disampaikan sesuai dengan tujuan pembelajaran, bahasa yang digunakan sederhana dan komunikatif, kata-kata yang digunakan sopan dan tidak menyinggung peserta didik dan katakata yang digunakan jelas dan tidak menimbulkan penafsiran ganda. Untuk validasi tes evaluasi terdiri atas tiga aspek yaitu: materi, konstruksi dan bahasa.

Data dianalisis secara deskriptif, validasi perangkat pembelajaran berupa validitas isi. Instrumen yang digunakan yakni lembar validasi film dokumenter, lembar validasi Rencana Pelaksanaan pembelajaran (RPP), Lembar Kerja Siswa (LKS), dan lembar validasi soal evaluasi. Efektivitas perangkat pembelajaran dapat dilihat dari skor tes hasil belajar siswa. Tes hasil belajar berbentuk pilihan ganda dengan jumlah 20 butir soal. Perangkat pembelajaran dikatakan efektif apabila skor tes hasil belajar berada di atas Kriteria Ketuntasan Minimal (KKM) yaitu 70.

\section{HASIL DAN PEMBAHASAN}

Hasil dari penelitian ini berupa perangkat pembelajaran meliputi media Film documenter, Rencana Pelaksanaan pembelajaran (RPP), Lembar Kerja Siswa (LKS), dan soal evaluasi materi ruang lingkup biologi. Film dokumenter yang dibuat berdurasi 37 menit 11 detik. RPP dan LKS dibuat untuk dua kali pertemuan pada proses pembelajaran.

Film dokumenter dapat digolongkan ke dalam jenis media audiovisual yang dapat memberikan informasi secara visual (diterima oleh mata) sekaligus audio (diterima oleh telinga). Dengan menggunakan film dokumenter siswa dapat melihat dan mendengar secara langsung objekobjek yang dipelajari pada materi ruang lingkup biologi. Selain itu dengan menggunakan film dokumenter, objek dan permasalahan biologi yang tidak bisa diperlihatkan secara langsung oleh guru pada film dokumenter divisualkan dan didefinisikan sehingga dapat membantu siswa belajar dengan mengamati secara langsung dan membuat siswa mudah mengingat materi pembelajaran. Objek biologi contohnya seperti objek yang dipelajari pada cabang-cabang ilmu biologi, misalnya ornitologi adalah cabang ilmu biologi yang mempelajari tentang burung. Sedangkan permasalahan biologi pada tingkatan organisasi kehidupan contohnya pada film dokumenter ditampilkan proses terjadinya penyakit osteoporosis yaitu hilangnya masa tulang sehingga tulang menjadi rapuh yang termasuk permasalahan biologi pada tingkat jaringan. 
Rencana Pelaksanaan

Pembelajaran (RPP) digunakan oleh guru sebagai panduan pelaksanaan dalam proses pembelajaran pada materi organisasi kehidupan. LKS berperan untuk membantu mengarahkan kegiatan siswa dalam mempelajari materi, sehingga membuat siswa mudah untuk mengingat materi yang dipelajari dan berpengaruh terhadap peningkatan hasil belajar siswa. Selain itu menurut Prastowo (2013) LKS juga berperan mempermudah pelaksanaan pengajar kepada siswa, mengaktifkan siswa dalam belajar, serta berperan sebagai bahan ajar yang mempermudah siswa untuk memahami materi yang diberikan.

Isi pada film dokumenter dimulai dengan pengenalan ilmu biologi yang mempelajari mengenai manusia, hewan, tumbuhan, dan mikroorganisme. Dengan Film dokumenter objek yang dipelajari siswa tidak bisa dibawa guru di depan kelas dapat divisualisasikan secara nyata pada siswa, sehingga mempermudah pemahaman siswa. Ketika siswa belajar dengan menggunakan film dokumenter, siswa belajar dengan menggunakan dua pancaindra yaitu mata dan telinga sehingga membuat siswa dapat mengingat materi yang dipelajari dengan baik. Penggunaan film dokumenter juga merupakan hal yang belum pernah diterima siswa, sehingga siswa memperoleh pengalaman baru dalam belajar. Ketika siswa mengamati dengan melihat gambar-gambar bergerak terus, ternyata juga dapat menyebabkan beberapa siswa tidak dapat mengikuti dengan baik isi dalam film dokumenter. Salah satu kekurangan film yaitu pada saat film dipertunjukkan, gambar-gambar bergerak terus sehingga tidak semua siswa mampu mengikuti informasi yang ingin disampaikan melalui film. Dapat dilihat pada Gambar 1.

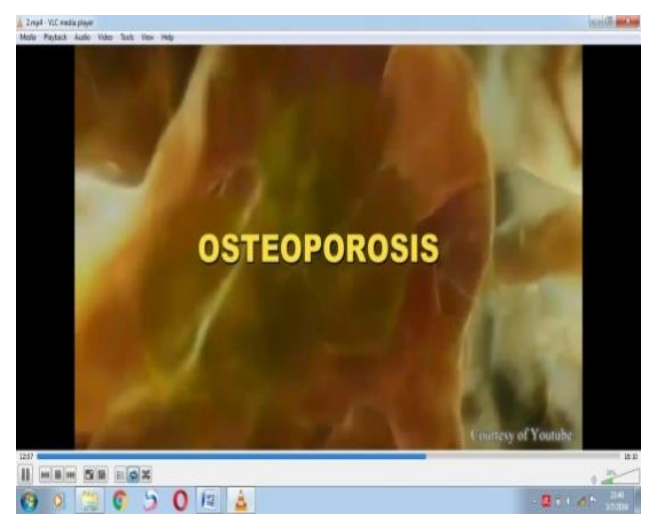

Gambar 1. Pengenalan Ilmu Biologi yang Mempelajari Mengenai Manusia, Hewan, Tumbuhan, dan Mikroorganisme.

Dilanjutkan dengan pembahasan mengenai beberapa cabang-cabang ilmu biologi, pembahasan mengenai pemanfaatan biologi dalam kehidupan, tingkat organisasi kehidupan, permasalahan biologi pada tingkat organisasi kehidupan dan kemudian film ditutup dengan pesan pentingnya belajar ilmu biologi bagi kehidupan.

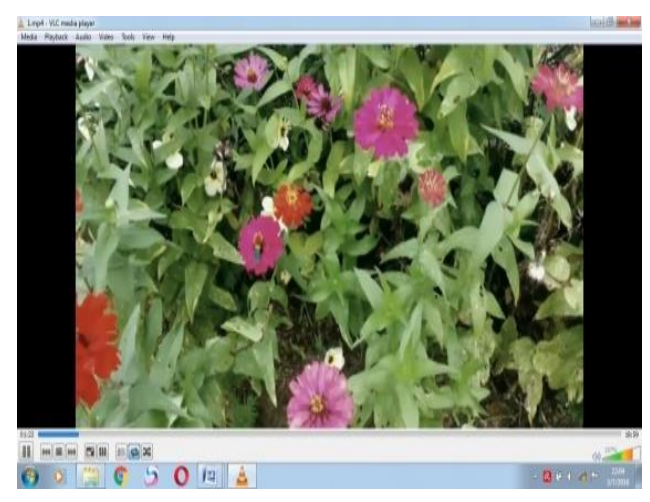

Gambar 2. Pembahasan Mengenai Permasalahan Biologi pada Tingkat Jaringan yaitu Osteoporosis. 
Hasil validitas perangkat lingkup biologi. Hasil validasi media pembelajaran menunjukkan bahwa pembelajaran untuk film dokumenter perangkat pembelajaran yang disusun dapat dilihat pada tabel di bawah ini: layak digunakan pada materi ruang

Tabel 1. Hasil validasi film dokumenter pada materi ruang lingkup biologi.

\begin{tabular}{|c|c|c|c|}
\hline Aspek & Kriteria Penilaian & $\Sigma V Y$ & $\Sigma V T$ \\
\hline \multirow[t]{3}{*}{ Organisasi } & $\begin{array}{l}\text { Materi yang digunakan dalam film dokumenter } \\
\text { sesuai dengan silabus pembelajaran }\end{array}$ & 3 & 0 \\
\hline & $\begin{array}{l}\text { Media film dokumenter yang dibuat sesuai dengan } \\
\text { tujuan pembelajaran }\end{array}$ & 3 & 0 \\
\hline & $\begin{array}{l}\text { Sistemmatika penyajiannya runut sehingga jalan } \\
\text { ceritanya mudah dimengerti }\end{array}$ & 3 & 0 \\
\hline Durasi & $\begin{array}{l}\text { Durasi film dokumenter tidak lama sehingga tidak } \\
\text { membuat siswa jenuh }\end{array}$ & 3 & 0 \\
\hline \multirow[t]{2}{*}{ Kemanfaatan } & $\begin{array}{l}\text { Media film dokumenter mempermudah guru dalam } \\
\text { menyampaikan materi }\end{array}$ & 3 & 0 \\
\hline & $\begin{array}{l}\text { Film dokumenter memberikan focus materi kepada } \\
\text { siswa }\end{array}$ & 3 & 0 \\
\hline \multirow{6}{*}{$\begin{array}{l}\text { Keefektifan } \\
\text { desain } \\
\text { tampilan }\end{array}$} & $\begin{array}{l}\text { Ukuran huruf yang digunakan dapat dengan jelas } \\
\text { dibaca dari dekat maupun jauh }\end{array}$ & 3 & 0 \\
\hline & $\begin{array}{l}\text { Warna huruf yang digunakan dapat dengan jelas } \\
\text { dilihat dari dekat maupun dari jauh }\end{array}$ & 3 & 0 \\
\hline & $\begin{array}{l}\text { Bentuk huruf yang digunakan dapat dengan jelas } \\
\text { dilihat dari dekat maupun jauh }\end{array}$ & 3 & 0 \\
\hline & $\begin{array}{l}\text { Komposisi warna tulisan dengan warna latar sesuai } \\
\text { sehingga tulisan dapat dibaca dan tidak } \\
\text { menyilaukan }\end{array}$ & 3 & 0 \\
\hline & $\begin{array}{l}\text { Kualitas gambar pada film dokumenter sudah } \\
\text { maksimal sehingga terlihat dengan jelas }\end{array}$ & 3 & 0 \\
\hline & $\begin{array}{l}\text { Narasi yang disampaikan jelas tanpa } \\
\text { mengakibatkan penonton sulit mengartikannya }\end{array}$ & 3 & 0 \\
\hline \multirow[t]{2}{*}{ Konsisten } & $\begin{array}{l}\text { Konsisten dalam pengguanaan kata, istilah, dan } \\
\text { kalimat }\end{array}$ & 3 & 0 \\
\hline & $\begin{array}{l}\text { Konsisten dalam penggunaan bentuk dan ukuran } \\
\text { huruf }\end{array}$ & 3 & 0 \\
\hline $\begin{array}{l}\text { Kemudahan } \\
\text { pengoperasian } \\
\text { media }\end{array}$ & Film dokumenter mudah dioperasikan & 3 & 0 \\
\hline
\end{tabular}

Kesimpulan

\section{Keterangan}

$\Sigma$ VY: Jumlah Validator yang Menjawab Ya

$\Sigma$ VT: Jumlah Validator yang Menjawab Tidak 
Rencana Pelaksanaan Pembelajaran pada materi ruang lingkup biologi dibuat 2 kali pertemuan. Hasil validasi untuk RPP yang dibuat dapat dilihat pada tabel dibawah ini:

Tabel 2. Hasil validasi rencana pelaksanaan pembelajaran (RPP)

\begin{tabular}{|c|c|c|c|c|c|}
\hline \multirow{2}{*}{ No } & \multirow{2}{*}{ Kriteria Penilaian } & \multicolumn{2}{|c|}{ RPP I } & \multicolumn{2}{|c|}{ RPP II } \\
\hline & & $\Sigma V Y$ & $\mathbf{\Sigma V T}$ & $\Sigma V Y$ & $\Sigma \mathrm{EVT}$ \\
\hline 1 & $\begin{array}{l}\text { Standar Kompetensi dan Kompetensi dasar } \\
\text { serta indikator telah sesuai dengan silabus }\end{array}$ & 3 & 0 & 3 & 0 \\
\hline 2 & $\begin{array}{l}\text { Tujuan pembelajaran telah sesuai dengan } \\
\text { indikator yang telah ditentukan pada silabus }\end{array}$ & 3 & 0 & 3 & 0 \\
\hline 3 & Menentukan langkah-langkah pembelajaran & 3 & 0 & 3 & 0 \\
\hline 4 & Menyiapkan instrument hasil belajar siswa & 3 & 0 & 3 & 0 \\
\hline & Rata-rata & 3 & 0 & 3 & 0 \\
\hline & Kesimpulan & & ayak I & unakar & \\
\hline
\end{tabular}

Keterangan

$\Sigma$ VY: Jumlah Validator yang Menjawab Ya

$\Sigma$ VT: Jumlah Validator yang Menjawab Tidak

Dalam penelitian disusun juga Lembar Kerja Siswa (LKS). LKS yang disusun berupa lembaran cetak yang berisi tugas yang didalamnya

berisi tugas yang dikerjakan oleh siswa. Adapun hasil validasi LKS dapat dilihat pada tabel dibawah ini:

Tabel 3. Hasil validasi lembar kerja siswa (LKS)

\begin{tabular}{clcccc}
\hline \multirow{2}{*}{ No } & \multicolumn{2}{c}{ Kriteria Penilaian } & \multicolumn{2}{c}{ LKS I } & \multicolumn{2}{c}{ LKS II } \\
\cline { 2 - 6 } & $\mathbf{\Sigma V Y}$ & $\mathbf{\Sigma V T}$ & $\boldsymbol{\Sigma} \mathbf{V Y}$ & $\boldsymbol{\Sigma} \mathbf{V T}$ \\
\hline 1 & Petunjuk penggunaan LKS tercantum jelas & 2 & 1 & 2 & 1 \\
\hline 2 & $\begin{array}{l}\text { Tujuan pembelajaran sesuai indikator dalam } \\
\text { silabus }\end{array}$ & 3 & 0 & 3 & 0 \\
\hline 3 & $\begin{array}{l}\text { Pertanyaan yang disampaikan sesuai dengan } \\
\text { tujuan pembelajaran }\end{array}$ & 3 & 0 & 3 & 0 \\
\hline 4 & $\begin{array}{l}\text { Bahasa yang digunakan sederhana dan } \\
\text { komunikatif }\end{array}$ & 3 & 0 & 3 & 0 \\
\hline 5 & $\begin{array}{l}\text { Kata-kata yang digunakan sopan dan tidak } \\
\text { menyinggung peserta didik }\end{array}$ & 3 & 0 & 3 & 0 \\
\hline 6 & $\begin{array}{l}\text { Kata-kata yang digunakan jelas dan tidak } \\
\text { menimbulkan penafsiran ganda }\end{array}$ & 3 & 0 & 0 \\
\hline & \multicolumn{3}{c}{$\begin{array}{c}\text { Layak Digunakan dengan } \\
\text { Perbaikan }\end{array}$} \\
\hline Kesimpulan
\end{tabular}

Keterangan

¿VY: Jumlah Validator yang Menjawab Ya

$\Sigma$ VT: Jumlah Validator yang Menjawab Tidak

Setelah melalui proses soal evaluasi kepada siswa. Hal pembelajaran pada materi ruang tersebut bertujuan untuk mengukur lingkup biologi guru memberikan sejauh mana siswa memahami materi 
yang telah disampaikan oleh guru. Soal evaluasi yang dibuat yaitu soal pilihan ganda dengan jumlah 20 butir soal. Terdapat tujuh tujuan pembelajaran yang diharapkan dapat dicapai oleh siswa setelah mempelajari ruang lingkup diologi antara lain: 1) menjelaskan pengertian biologi, 2) mengidentifikasi cabangcabang ilmu biologi, 3) memberikan contoh manfaat biologi bagi kehidupan, 4) mengurutkan tingkat organisasi kehidupan dari sederhana hingga kompleks, 5) menjelaskan setiap tingkat organisasi kehidupan, 6) menentukan objek biologi pada berbagai tingkat organisasi kehidupan dan 7) memberikan contoh permasalahan biologi pada berbagai tingkat organisasi kehidupan.

Adapun hasil validasi soal evaluasi dapat dilihat pada tabel dibawah ini:

Tabel 4. Hasil validasi soal evaluasi pada materi ruang lingkup biologi.

\begin{tabular}{|c|c|c|c|}
\hline $\begin{array}{c}\text { Bidang } \\
\text { Penelaah }\end{array}$ & Kriteria Penilaian & $\Sigma \mathbf{V Y}$ & $\Sigma \mathbf{V T}$ \\
\hline \multirow[t]{4}{*}{ Materi } & Rumusan soal sesuai dengan indicator & 2 & 1 \\
\hline & $\begin{array}{l}\text { Batasan jawaban atau ruang lingkup yang } \\
\text { diuji sudah jelas }\end{array}$ & 2 & 1 \\
\hline & $\begin{array}{l}\text { Isi materi yang dinyatakan sesuai dengan } \\
\text { pengukuran }\end{array}$ & 3 & 0 \\
\hline & $\begin{array}{l}\text { Isi materi yang dinyatakam sesuai dengan } \\
\text { jenjang atau tingkat sekolah }\end{array}$ & 3 & 0 \\
\hline \multirow[t]{3}{*}{ Konstruksi } & $\begin{array}{l}\text { Rumusan butir soal sudah menggunakan } \\
\text { tanda tanya atau perintah menurut } \\
\text { jawaban soal }\end{array}$ & 1 & 2 \\
\hline & $\begin{array}{l}\text { Rumusan butir soal sudah disertai } \\
\text { pedoman penskoran }\end{array}$ & 3 & 0 \\
\hline & $\begin{array}{l}\text { Rumusan butir soal tidak menimbulkan } \\
\text { penafsiran ganda }\end{array}$ & 3 & 0 \\
\hline \multirow[t]{4}{*}{ Bahasa } & $\begin{array}{l}\text { Rumusan butir soal sudah menggunakan } \\
\text { bahasa yang sederhana sehingga } \\
\text { komunikatif }\end{array}$ & 3 & 0 \\
\hline & $\begin{array}{l}\text { Bahasa soal tidak menyinggung peserta } \\
\text { didik }\end{array}$ & 3 & 0 \\
\hline & $\begin{array}{l}\text { Rumusan soal tidak menimbulkan } \\
\text { penafsiran ganda atau salah pengertian }\end{array}$ & 3 & 0 \\
\hline & $\begin{array}{l}\text { Soal menggunakan bahasa Indonesia yang } \\
\text { baik dan benar }\end{array}$ & 3 & 0 \\
\hline \multicolumn{2}{|r|}{ Kesimpulan } & $\begin{array}{l}\text { Layak } \\
\text { Digunakan } \\
\text { dengan } \\
\text { Perbaikan }\end{array}$ & $\begin{array}{c}\text { Layak } \\
\text { Digunakan }\end{array}$ \\
\hline
\end{tabular}

Keterangan

¿VY: Jumlah Validator yang Menjawab Ya

¿VT: Jumlah Validator yang Menjawab Tidak

Berdasarkan hasil validasi oleh saran yang diberikan oleh validator validator, ada beberapa komentar dan untuk memperbaiki perangkat 
pembelajaran. Komentar dan saran validasi untuk film dokumenter huruf pada tulisan di film dokumenter perlu variasi warna, narasi divariasikan, dan kualitas pada beberapa scene ada yang kurang maksimal. Komentar dan saran validasi untuk RPP pada rumusan tujuan pembelajaran ditambahkan unsur C "Condition", alokasi waktu disesuaikan dengan kegiatan pembelajaran, dan langkahlangkah pembelajaran disesuaikan dengan tahapan eksplorasi, elaborasi, dan konfirmasi. Komentar dan saran validasi untuk LKS pada petunjuk pengerjaan LKS lebih diperjelas, untuk beberapa soal disatukan dalam bentuk tabel, gambar pada beberapa soal diganti dengan yang lebih jelas, skor jawaban pada soal tentang menjelaskan pengertian tiap tingkatan organisasi kehidupan ditambah. Komentar dan validasi untuk soal evaluasi pada soal no 3 menjelaskan pengertian biologi pengecoh jawaban pilihan gandanya diganti, pada soal no 19 mengidentifikasi cabangcabang ilmu biologi kalimat pilihan ganda diperbaiki sehingga lebih singkat, pada soal no 8 memberikan contoh permasalahan biologi pada berbagai tingkat organisasi kehidupan dan 17 memberikan contoh manfaat biologi bagi kehidupan kalimat pertanyaan soalnya lebih diperjelas, dan pada soal 18 mengidentifikasi cabang-cabang ilmu biologi dan 20 mengurutkan tingkat organisasi kehidupan dari sederhana hingga kompleks soal disesuaikan dengan indikator soal.

Keefektifan

perangkat

pembelajaran juga menunjukkan nilai hasil belajar siswa sebesar $84,37 \%$ mencapai kriteria ketuntasan minimal $(\mathrm{KKM})$, dengan nilai rata-rata hasil belajar siswa pada materi ruang lingkup biologi adalah 75,78. Hasil pada penelitian ini sejalan dengan hasil penelitian yang dilakukan oleh Dewi, dkk (2013), yang mengungkapkan bahwa pengembangan perangkat IPA terpadu dapat meningkatkan hasil belajar siswa, yang berarti perangkat pembelajaran efektif untuk digunakan. Dari hasil validasi menunjukkan bahwa film dokumenter, Rencana Pelaksanaan Pembelajaran (RPP), Lembar Kerja Siswa (LKS), dan soal evaluasi layak digunakan sebagai perangkat pembelajaran pada materi ruang lingkup biologi. Menurut Nieven (dalam Khabibah, 2006) suatu material dikatakan baik jika memenuhi aspek-aspek kualitas, antara lain: (1) Validitas ( Validity), (2) Kepraktisan (Practicaly), dan (3) Keefektifan (Effectiveness). Berdasarkan hasil penelitian ini sudah terlihat bahwa perangkat pembelajaran sudah valid dan efektif.

\section{SIMPULAN DAN SARAN}

Berdasarkan hasil penelitian, maka dapat ditarik kesimpulan: Hasil validasi perangkat pembelajaran berupa film dokumenter, Rencana pelaksanaan Pembelajaran (RPP), Lembar Kerja Siswa, Soal evaluasi dinyatakan layak digunakan sebagai perangkat pembelajaran. Perangkat pembelajaran yang disusun efektif dalam meningkatkan hasil belajar terlihat dari rata-rata hasil belajar sebesar 75,78 dan mencapai ketuntasan minimal sebesar 84,37\%. Saran yang dapat diberikan dalam penelitian pembuatan perangkat pembelajaran sejelas mungkin agar tidak terjadi kesalahan 
dalam penafsiran. Dengan membuat perangkat pembelajaran tersebut, maka dapat dilakukan pembelajaran sesuai dengan yang direncanakan.

\section{DAFTAR PUSTAKA}

Aziz, A. 2013. Makalah Perangkat Pembelajaran. (Online). (http://abdaaziiz.blogspot.co.id, diakses 7 Maret 2016)

Arsyad, A. (2011). Media pembelajaran. Jakarta: Rajawali Pers.

Darwanto.(2007). Televisi Sebagai Media Pendidikan. Yogyakarta: Pustaka belajar.

Dewi, K., Sadia, I.W., \& Ristiati, N.P. (2013). Pengembangan Perangkat Pembelajaran IPA Terpadu dengan Setting Inkuiri Terbimbing untuk Meningkatkan Pemahaman Konsep dan Kinerja Ilmiah Siswa. E-journal Program Pascasarjana Universitas Pendidikan Ganesha. Vol. 3.

Jihad, A dan Haris, A. (2012). Evaluasi Pembelajaran. Yogyakarta: Multi Pressindo Yogyakarta

Khabibah, S. (2006). Pengembangan Model Pembelajaran Matematika dengan Soal Terbuka untuk Meningkatkan Kreativitas Siswa Sekolah Dasar.Disertasi.Surabaya:

Program Pasca. Sarjana Universitas Negeri Surabaya.
Ma'rifah D.R dan Suryadarma, I.G.P. (2015). Penyusunan Panduan EDUTOURISM Hutan Wisata Tlogo Nirmolo Guna Memunculkan Karakter Peserta Didik Kelas X. Jurnal Inovasi Pendidikan IPA. Vol 1 Nomor 2 Hal 126-137

Majid, Abdul. (2013). Perencanaan Pembelajaran: Mengembangkan Standar Kompetensi Guru. Bandung: PT Remaja Rosdakarya

Munadi, Y. (2013). Media Pembelajaran. Jakarta: GP Press.

Mulyasa, E. (2011). Kurikulum Tingkat Satuan Pendidikan: Sebuah Panduan Praktis. Bandung: Rosda

Pratista, H. (2008). Memahami Film. Yogyakarta: Homerian Pusaka.

Prastowo. (2013). Panduan Kreatif Membuat Bahan Ajar Inovatif. Yogyakarta: Diva Press

Sadiman, dkk. (2011) Media Pendidikan Pengertian,

Pengembangan dan

Pemanfaatannya. Jakarta: Pustekkom dan PT Raja Grafindo

Sudjana dan Rivai.(2010). Media Pengajaran. Bandung: Sinar Baru Agresindo. 